\title{
O mar na poesia de Manuel da Fonseca: exercício de análise
}

\section{The sea in the poetry of Manuel da Fonseca: an exercise of analysis}

Antony Cardoso Bezerra

Universidade Federal Rural de Pernambuco, Recife, Pernambuco Brasil Bezerra.a.c@gmail.com

Resumo: Estreando-se na Literatura como poeta, Manuel da Fonseca construiu uma obra lírica breve, mas significativa. Por meio de uma problematização sobre o estatuto do projeto literário neorrealista - em que o autor se pode incluir - e dos papéis por que se configura a noção de poesia moderna, analisa-se, num corpus de 11 textos de Fonseca, a presença do mar como "figura poética", conforme Maria Alzira Seixo a conceituou. Nota-se que o mar tanto se apresenta como espaço privilegiado de liberdade, bem como representação da vida; seja num alcance historicamente ancorado, seja numa dimensão mais ampla, em clave de abstração.

Palavras-chave: Manuel da Fonseca; Neorrealismo; poesia; figura; mar; vida.

Abstract: Manuel da Fonseca debuted in Literature as a poet. His lyric poems compose a brief-but significant-work. Through a problematization of the status of the neorealist literary project (a movementin which the author was a participant) and of the so-called modern poetry, 11 of Fonseca's texts are analysedby considering the presence of the sea as a "poetic figure", as Maria Alzira Seixo conceptualized it. It is noted that the sea both presents itself as a noteworthy space of freedom, as well as a representation of life; either in a historically based mode, or in a broader dimension, with an abstract bias.

Keywords: Manuel da Fonseca; Neorealism; poetry; figure; sea; life. 
Recebido em 15 de março de 2017

Aprovado em 26 de maio de 2017

Escritor de longeva atividade literária, Manuel da Fonseca ${ }^{1}$ não é autor de uma obra extensa. Na condição de poeta, tal quadro se apresenta ainda com maior nitidez, dado o caráter apenas ocasional da produção de poemas líricos, que se podem enfeixar em cerca de 150 páginas impressas, número variável em decorrência da edição que se tenha em mãos. Não é fator que o desautorize. Notabilizado por filtrar com denodo o que converte em publicação e por uma concisão e um poder de síntese que resultam do trabalho - "Ser espontâneo dá trabalho", diz o próprio Fonseca (apud FERREIRA, 1986, p. 89) -, não parece incorreto sustentar que a obra do homem de letras alentejano seja marcada por um equilíbrio e por uma homogeneidade qualitativa pouco usuais em seu horizonte.

Estreando-se em volume precisamente com uma reunião de poemas, Rosa dos ventos (1940), Manuel da Fonseca tem boa parte da sua produção lírica concentrada na alvorada do Neorrealismo, tendência a que sua obra é tradicionalmente vinculada. De 1941 é o livro Planície, sexto volume do que é um marco da poesia neorrealista, a série "Novo Cancioneiro". Rosa dos ventos e Planície fornecem a base dos dois outros títulos da lírica do autor alentejano: Poemas completos $(1958 ; 1963)$, acrescidos, na 2. ${ }^{a}$ ed., dos "Poemas dispersos", e Obra poética (1984), a que foram aduzidos os "Poemas para Adriano", versos compostos pelo poeta entre 1972 e 1973 e musicados pelo cantor Adriano Correia de Oliveira, cujo disco Que nunca mais: Adriano canta Manuel da Fonsecasaiu em 1975. Ou seja, está-se diante de uma coleção que se fez aos poucos e com vagar. Para o presente estudo, consideram-se a 3 . $^{\mathrm{a}} \mathrm{ed}$.

\footnotetext{
${ }^{1}$ Manuel da Fonseca (n. 1911, em Santiago de Cacém; f. 1993, em Lisboa) é um dos nomes-chave da tendência literária que se convencionou chamar Neorrealismo. Dedicou-se mormente à escrita em prosa, de que se podem destacar (1) os romances Cerromaior (1943) e Seara de vento (1958); (2) os volumes de contos Aldeia nova (1942), O fogo e as cinzas (1951), Um anjo no trapézio (1968), Tempo de solidão (1973) e À lareira, nos fundos da casa onde o Retorta tem o café (2000); e (3) os volumes de crônicas Crônicas algarvias (1986), O vagabundo na cidade (2001) e Pessoas na paisagem (2002). Constituem-se, as edições póstumas, em recolhas de textos que o escritor publicara em periódicos. De sua obra poética, oferece-se detalhamento no corpo do artigo, haja vista se constituir, ela, como o foco das investigações.
} 
de Poemas completos (FONSECA, 1969), título que o autor rechaça na edição renomeada Obra poética (FONSECA, 1984) - em verdade, a 7. a ed. da poesia reunida do autor -: "[Poemas completos] Sempre me dera a ideia que, reunidos sob este título, os dois livros Rosa dos ventos e Planície, o poeta pedira a demissão. Não sei a quem nem por quê, mas pedira. O que não foi nem é o caso". (FONSECA, 1984, p. 13). Não pediu demissão e nem poderia, pois do escritor Manuel da Fonseca, independentemente do gênero em que atue, não se ausenta a veia lírica, o que, em palavras precisas, fez salientar Maria Alzira Seixo: "Começa a ser poeta $[\ldots]$ e sê-lo-á até ao fim. Contando contos que poderíamos entender como prosa lírica, e por duas vezes prolongou em sequências com fôlego de romance [...].” (SEIXO, 2011, p. 55).

É à lírica consubstanciada em versos e em poemas que ora se destina atenção; mais precisamente, à que visita uma instância assídua na tradição literária portuguesa e que se materializa em sentido multiforme nos 11 poemas que compõem o corpus do estudo - o mar, que vem na forma do lexema ele mesmo ou por meio de alusões. ${ }^{2}$ Não se constituindo como a principal chave para a fixação do projeto lírico do autor (que, talvez, seja o vento e sua atuação no campo alentejano), ${ }^{3}$ nem por isso o mar desempenha um papel à margem de sua lírica, prova do que é o fato de existir um número expressivo de peças que o visitem e, mais, do que pode simbolizar em face dos fios condutores da Literatura de Fonseca como um todo.

A integração do autor em foco a um dos grupos de jovens que dariam corpo ao Neorrealismo é caracterizada por Mário Dionísio, amigo de longa data do escritor santiaguense: era Lisboa, 1937 (ou 1938), quando "Manuel da Fonseca nos apareceu, tão irritado com as 'torres de

\footnotetext{
${ }^{2}$ Eis os poemas em questão: de Rosa dos ventos, "Quarta" e "Sétima" das "Sete canções da vida"; a série "Canções da beira-mar", composta por "Saudade", "Partir!...", "Canção da beira-mar", "O vagabundo do mar", "Noite" e "Canção de Hans, o marinheiro"; "Noturno", de "O vagabundo e outros motivos alentejanos"; "Os Olhos do poeta", de "Poemas (primeira parte)"; e "Invernia", de Poemas dispersos (1937-1962).

${ }^{3}$ Trata-se de algo que o próprio tende, em certa medida, a reconhecer. Numa entrevista concedida à Gazeta musical e de todas as artes, quando, ao assinalar a validade da atividade de crítico literário, destaca o papel de um exegeta de sua obra que foi capaz de mapear a presença constante do vento nos poemas e contos no caminho que pavimentou a chegada ao romance Seara de vento (DIÁLOGO, 1960, p. 57). O vento, como o spiritus latino, é também espírito, que traz a vida.
} 
marfim' (vocabulário obrigatório à época) e tão disposto a tudo reformar como qualquer um de nós." (DIONISIO, 1984, p. 22.) Projeta-se, aqui, a oposição ao regime do Estado-Novo e à geração da revista coimbrã Presença (1927-1940), reconhecida representante do status quo literário de então. Flagra-se, na contraposição entre tendências literárias, uma marca daquilo em que consiste o processo de evolução literária - a contradição do projeto, uma desautorização (muitas vezes virulenta) das produções em voga, com a realização do grupo em ascensão, que acaba por recuperar (e, claro, suplementar) aspectos das manifestações daqueles que se atacam. ${ }^{4}$ No caso dos escritos neorrealistas, a posição de rebeldia incide nos que fazem as vezes de alvo. Um ator destacado do Presencismo, o crítico e ficcionista João Gaspar Simões, delineia, em retrospectiva, um panorama que não parece fugir à verdade de como se comportam os autores da nova geração em face dos antecessores que buscam desautorizar. Diante de uma conjuntura histórica tumultuosa, a da década de 1930,

O esteticismo da Presença já não satisfazia a consciência dos intelectuais que se encontravam agora diante de uma realidade político-social nada tranquilizadora. A situação do homem era outra, e havia que pensar em servir uma causa que ao escritor se afigurava inseparável do destino da

\footnotetext{
${ }^{4}$ Carlos Reis propõe uma justa caracterização das negociações que envolvem a problemática dos períodos literários, que "surgem como fenômenos dinâmicos, compreendidos no devir de uma evolução e implicando, com frequência, uma certa conflitualidade." (REIS, 2001, p. 382-383) Dentro desse processo, o que se pode verificar é uma "relativa estabilidade, assegurada pela instituição literária de vários modos e através de diversos instrumentos", mas que jamais marcará um equilíbrio absoluto (REIS, 2001, p. 391). É essa a condição que parece caracterizar o embate entre presencistas (mantenedores do status quo) e neorrealistas. Ademais, na esteira do que afirma Eduardo Lourenço, deve-se ter em conta de que, no Neorrealismo, há uma "precedência histórica e ideal da teoria sobre a visão literária", que não dá conta de como o movimento "é uma manifestação mais complexa, contraditória, dinâmica, viva, do que as aparências fazem crer." (LOURENÇO, 1983, p. 13). E, mais, que "não podemos deixar de ler [o discurso poético neorrealista] no horizonte da palavra poética 'presencista', modernista, dos 'Cadernos de Poesia', do surrealismo e, por fim, de toda a nossa tradição poética." (LOURENÇO, 1983, p. 22). A tematização do mar na lírica de Manuel da Fonseca é bem uma prova literária desse quadro, conforme se demonstra adiante.
} 
própria literatura. Eis porque a finalidade sem fim da arte apregoada pela Presença se torna, aos olhos da geração que desponta, indesejável e quase odiosa. Um antagonismo ideológico opõe os poetas do Novo Cancioneiro aos poetas presencistas, e é esse antagonismo ideológico que os faz esquecer as afinidades estéticas profundas que mantêm solidárias as gerações do modernismo com as gerações do neorrealismo. (SIMÕES, 1964, p. 356)

Dentre as questões que assomam do juízo do analista, uma merece desdobramento para os fins da presente investigação: destoará, a Literatura neorrealista (e, mais particularmente, a poesia) da condição moderna? Se a preocupação com um tal enquadramento é marcante em Presença - quando de seu início, sobretudo -, não está na superfície da crítica neorrealista, do que é prova a seguinte passagem de "Algumas notas para uma nova poética" (1937), de Manuel Filipe, texto em que se evidencia o pendor programático dos escritos que caracterizam a antessala das primeiras manifestações literárias. Diz o crítico: "A arte toda a arte - na severidade das suas linhas é periodicamente necessária. Mas notai bem: a poesia é síntese. Não é nem música, nem a imagem, nem a ideia; ela é ao mesmo tempo tudo isso.” (FILIPE, 1981, p. 221). O que vale apontar é o fato de, embora, ao longo do texto, ensaie uma defesa do papel social do poeta, Filipe não desfaça do caráter do texto poético e da capacidade de amalgamar o comunitário e o individual, numa leitura do mundo que não caiba num panfleto - "a caricatura [...] segundo a qual o neorrealismo teria sido, em bloco, um movimento exclusivamente interessado pela descrição-denúncia [...] do homem social no que este tem de mais exterior [...].", conforme observará Dionísio ([19_], p. 23) no “Antiprefácio" a sua Poesia incompleta. Em certa medida, o saldo que se pode haurir desse debate é o entendimento de que somente a descida à obra individualizada dos autores pode pôr em xeque as reduções que fatalmente derivariam de um estudo que privilegiasse as idas e vindas da vida social e cultural em detrimento da produção literária propriamente dita. Noutros termos - e com as atenções voltadas para a lírica de Manuel da Fonseca -, os autores são sempre maiores que os grupos a que intencionalmente se vinculam ou em que a posteridade os situa. No caso do poeta alentejano, embora não despida de propósito, a insistência na motivação e nos desdobramentos ideológicos de suas composições talvez sirva para a compreensão de um determinado 
horizonte histórico, mas se mostra ineficaz para a composição do perfil que os seus poemas assumem. ${ }^{5}$ Mesmo porque "Obras de arte [...] têm sua grandeza unicamente em deixarem falar aquilo que a ideologia esconde. Seu próprio êxito, quer elas queiram ou não, passa além da falsa consciência.", é o que propõe Theodor W. Adorno e que, em certo sentido, parece definir a grande lírica em sua condição multifacetada e plurissignificativa (ADORNO, 2003, p. 68).

Muito em decorrência da condição ventilada pelo filósofo alemão, parece redutora a defesa sustentada por Simões, segundo a qual efetivamente modernas seriam as gerações de Orpheu e de Presença, esta se desdobrando daquela; não a do Neorrealismo. O estatuto da poesia moderna, segundo Alfonso Berardinelli, não se constitui por uma linhagem apenas; aquela que se poderia ver no poeta francês Stéphane Mallarmé, p. ex. (cf. BERARDINELLI, 2007, p. 17-19), e que, no Portugal da ascensão do Presencismo, materializou-se na noção da criação poética como "um fenômeno de contornos espiritualistas, capaz de conduzir a estádios de vivência mística e transcendente.” (REIS, 1983, p. 77). Assumindo-se o crítico italiano como guia, pode-se chegar às reflexões do dublê de poeta e crítico T. S. Eliot e à noção de que a poesia moderna pode encarnar, pelo menos, três condições/vozes: a do poeta falando consigo próprio (ou com ninguém); a do poeta que se dirige a uma audiência; e a do poeta que tenta criar uma personagem dramática que se expressa em verso (ELIOT, 1969, p. 96). Manuel da Fonseca, muito

\footnotetext{
${ }^{5}$ Não são poucos os exemplos de críticos que, a partir do propósito de salientar o ideológico e o poder de intervenção da lírica de Manuel da Fonseca, acabem por (conscientemente ou não) subordinar a realização literária a um projeto ideológico. Para se ficar numa ilustração, pode-se recorrer ao bom ensaio de Maria de Lourdes Belchior, que, embora reconhecendo que "O poema faz-se com palavras e nestas se revelam as obsessões e as crenças, os sonhos e os traumas do homem e da sociedade.", acredita que a decifração da poesia de Manuel da Fonseca "poderá encaminhar-nos para os códigos ideológicos de que consciente ou inconscientemente o poeta se socorre." (BELCHIOR, 1980, p. 14-15.) É por isso que se aceita, aqui, a senda demonstrada por Fernando Guimarães, que, escudado em Álvaro Manuel Machado, defende: "[as implicações de um texto poético exigem] uma atitude de leitura que não se esgote numa mera decifração com intuitos ideológicos, embora o sentido ideológico se possa configurar a partir de várias derivas em que ele é ganho e, ao mesmo tempo, se perde, ficando a oscilar entre essa perda e essa recuperação possíveis. Em cada palavra podemos encontrar múltiplos caminhos." (GUIMARÃES, 2011, p. 71)
} 
claramente - e sem deixar de ser moderno -, frequenta a segunda e a terceira tradições. Seja pela projeção nas individualidades populares que são, também, um eco das tensões da coletividade; seja pela conclamação (não grandíloqua ou artificial, bom salientar) à mudança, a que se faça "qualquer coisa de louco e heroico", como diz o eu lírico do antológico "Mataram a tuna!" (FONSECA, 1969, p. 119). De certa maneira, o que Adorno (2003, p. 67) pensou em termos das relações entre a lírica e a sociedade bem se ajusta à leitura da poesia de Manuel da Fonseca:

[...] a interpretação social da lírica [deve] estabelecer como o todo de uma sociedade, tomada como unidade em si mesma contraditória, aparece na obra de arte; mostrar em que a obra de arte lhe obedece e em que a ultrapassa. [...] Conceitos sociais não devem ser trazidos de fora às composições líricas, mas sim devem surgir da rigorosa intuição delas mesmas.

A negociação entre universal e individual que atravessa o que de melhor produziu a lírica neorrealista propicia um entendimento amplo do que motiva o entorno de Manuel da Fonseca, sem que, por isso, o alcance da voz poética a esse mundo se circunscreva. Mesmo falando de um lugar distinto daquele ocupado pelo teórico alemão, T. S. Eliot acaba por convergir com o seu contraparte: "na tentativa de se entender adequadamente a poesia de um período somos levados a considerar assuntos que à primeira vista parecem ter pouca importância para a poesia. Esses assuntos têm, consequentemente, muito a ver com a crítica de poesia [...]." (ELIOT, 2015, p. 83). No fim de contas, a lírica - tenha pretensão interventiva ou não ${ }^{6}$ - comunica, já por ser vazada na linguagem humana. A propósito, vale socorrer-se de Northrop Frye para o reforço de tal estatuto e, consequentemente, para compreender sua concretização na obra do poeta em estudo. Diz o autor canadense:

Poesia é, afinal de contas, uma técnica de comunicação: ela envolve tanto a parte consciente da mente quanto suas áreas mais obscuras, e aquilo que um poeta consegue comunicando-se com os outros é, de qualquer forma, tão

\footnotetext{
${ }^{6}$ É, nesse sentido, esclarecedora a consideração de Michael Hamburger: “As diferenças genuínas entre os poetas vêm à luz por causa do valor que cada um atribui às funções e implicações públicas da poesia [...].” (HAMBURGER, 2007, p. 58)
} 
importante quanto aquilo que não consegue resolver para si mesmo.

$[\ldots]$

A estrutura do poema continua sendo um esforço para a comunicação, não obstante possa deixar totalmente de comunicar. (FRYE, 1973, p. 19-20)

A nítida capacidade de Fonseca, consistente em se apropriar de elementos da linguagem popular - na seleção lexical, na sintaxe, no metro etc. -, fá-lo, ao mesmo tempo, dialogar com o seu próprio mundo e com atores vinculados a diferentes tradições literárias, tais como Florbela Espanca, Fernando Pessoa/Álvaro de Campos e o Federico García Lorca dos romances, aproximação, esta, tão recorrente entre os analistas da obra do poeta português (cf. SIMÕES, 1964; BELCHIOR, 1980; GUSMÃO, 2011; SEIXO, 2011; et al.). Nesse sentido, amalgama-se a fonte livresca com o espaço da memória, "do que a vida e as gentes conhecidas sempre lhe ensinaram e foram matéria e razão de ser da sua arte literária.”, nas palavras de Serafim Ferreira (1986, p. 86). Embora compartilhando de uma vivência urbana desde a adolescência, os sinais da infância alentejana não deixarão de o marcar profundamente, ainda que o poeta não os aceite em termos definitivos e restringentes (cf. DIÁLOGO, 1960, e DIONÍSIO, 1969). Em certo sentido, a poesia do autor tem, na ambiência do Alentejo, um plano privilegiado pelo qual circulam as figuras essenciais de sua lírica - os tipos (malteses, camponeses, funcionários et al.), os elementos da natureza (o vento, as aves, os campos etc.), bem como os desníveis sociais. Esse grupo remete ao que Frye (1973, p. 20) chamou de "estrutura imagística" da obra de um poeta. Longe de ser privada, nem por isso deixa de assumir feições particulares na produção individual. "E certamente o contexto literário mais indicado para um poema é a produção literária completa de seu autor." (FRYE, 1973, p. 19). No interior dessa esfera, identifica-se o que Seixo, pensando na produção do próprio Manuel da Fonseca, entende por "figuras poéticas":

[...] o conjunto de significação que, em poesia lírica, abrange personagens e entidades de relação contextual diversa, tais como o corpo paisagístico, certos motivos simbólicos animizados, e outros elementos insistentes na caracterização de coisas e de seres, verificamos que na poesia de Manuel da Fonseca emerge uma figuração abundante deste teor. (SEIXO, 2011, p. 58) 
É nessa condição que se percebe o mar, um dentre os elementos naturais com que o homem interage e de que fala. Entrementes, ele remete a tudo menos à permanência; evidente: nele, não há raízes. $\mathrm{O}$ mar mais parece levar para longe do Alentejo, na desmedida rebelde, do que conduzir ao cultivo do espaço ancestral. Na consideração, assim, dessa figura poética, aquilo que disse Adorno (2003, p. 70) sobre o fazer do poeta moderno parece convergir para a lírica de Fonseca: "Somente através da humanização há de ser devolvido à natureza o direito que lhe foi tirado pela denominação humana da natureza." Embora a condição exposta soe redutora, é bem certo que rime com o projeto e a realização do poeta português. Em certo sentido, também esse fator aflora na análise dos poemas. ${ }^{7}$

Se o Alentejo se apresenta como o espaço principal espaço da poesia de Manuel da Fonseca, é a partir dele - e, mais especificamente, de seu interior - que se chega ao mar para que deste se tenha conhecimento e que se apreenda toda a carga de implicações, literárias ou históricas. Enunciada na terceira pessoa do singular, "Saudade", a primeira das "Canções da beira-mar", cede a voz à individualidade e à coletividade.

... Ora veio um moço do interior e viu o mar: ficou maravilhado!
Mas que chorava aquela gente olhando aquele assombro?
Mil vozes gemeram: - O nevoeiro que anda nas águas...
E o moço estranhou a origem de tanta dor:
- O mar que eu vejo é azul e simples, entorna frescura.

(FONSECA, 1969, p. 22)

Do fato de, no seio da nau perdida no oceano, ter-se se instalado "o silêncio das coisas mortas", a ecoar na alma dos marinheiros que sentem apenas saudade, gera-se a noção de que em "qualquer parte o mar é tenebroso" (FONSECA, 1969, p. 22). A alusão à expansão ultramarina lusa - constante na tradição literária portuguesa e não ausente do corpus de poemas de Manuel da Fonseca - faz-se sentir no texto, ainda que problematizada por uma dimensão despida de exaltação e que se configura numa dimensão tripartite. Às naus e ao porto de partida, em que se confrontam um passado de promessa e um presente

\footnotetext{
${ }^{7}$ Dada a brevidade do estudo e a condição pontual da análise, opta-se por não se enfatizarem os padrões formais dos poemas, privilegiando-se, de outro lado, o plano da expressão numa condição mais geral - seleção lexical, sintaxe, imaginário etc.
} 
de desilusão, opõe-se a visão do jovem do interior que é só presente; da projeção de uma individualidade que não contém a carga negativa da que se encontra na coletividade. "-O mar que eu vejo é azul e simples, entorna frescura." A ideia da palavra virginal, primeira, se concretiza no olhar do poeta, num sentido que Adorno (2003, p. 68), a ocupar-se da poesia lato sensu, entende como uma demanda social. O moço do interior (que, evidentemente, sustenta-se aqui como o alter ego ficcional do poeta), assim, a ver no mar apenas a sua superfície (a canção se faz à "beira-mar"; a palavra é que o leva para longe), converte-se, imolado pela turba que o chama "Sacrílego!", no "farol das naus perdidas no nevoeiro!" (FONSECA, 1969, p. 22). É do fogo que o consome que se guiam os que estão à volta; ou a palavra poética, em sua condição primeva, que mostra aos demais o caminho que se deva seguir. O mar, aqui, é a "lonjura" de que fala Eudoro de Sousa, enquadrada em "outrora" (1981, p. 3 ss.), e é o poeta que espacializa e temporaliza tal esfera; noutros termos, historiciza e, por isso, humaniza. ${ }^{8}$ Em "Noite", a sexta das "Canções da beira-mar", os "Milhões de barcos perdidos no mar! / Perdidos na noite!" estão em apuros na imensidão e nos riscos que o mar oferece. Se, em "Saudade", o poeta é sacrificado para proporcionar o fogo que guia, em "Noite", o eu poético invoca a instância oculta que possa salvar os navegadores da escuridão (da vida, da realidade histórica?): “Quem vem acender faróis na costa do mar bravo?! / Quem?!" (FONSECA, 1969, p. 30).

Embora, do ponto de vista da pessoa lírica, o primeiro contato com o mar seja materializado nos versos de "Saudade", conforme a ordem disposta na edição de Poemas completos de Manuel da Fonseca e, dentro deste volume, o livro de estreia do autor, Rosa dos ventos, a primeira referência ao mar se vê na "Quarta" das "Sete canções da vida". O texto é enunciado na primeira pessoa do plural - o que assinala certa tendência ao convite e à condição gregária de parcela da lírica de Fonseca - e junta dois tempos: o do passado, em que muito já foi feito, e o do porvir, da colheita.

\footnotetext{
${ }^{8}$ A ideia do mar como lonjura também está presente na "Sétima" das "Sete canções da vida": "Entontecido / como asa que se abre para o azul / abarco a Vida toda / e parto / para os longes mais longes das distâncias mais longas / sei lá de que destino ignorados!" (FONSECA, 1969, p. 16). No poema, vigora a imprevisibilidade do que o mar possa guardar e, já por isso, uma visão futurante (que se situa a partir do passado).
} 


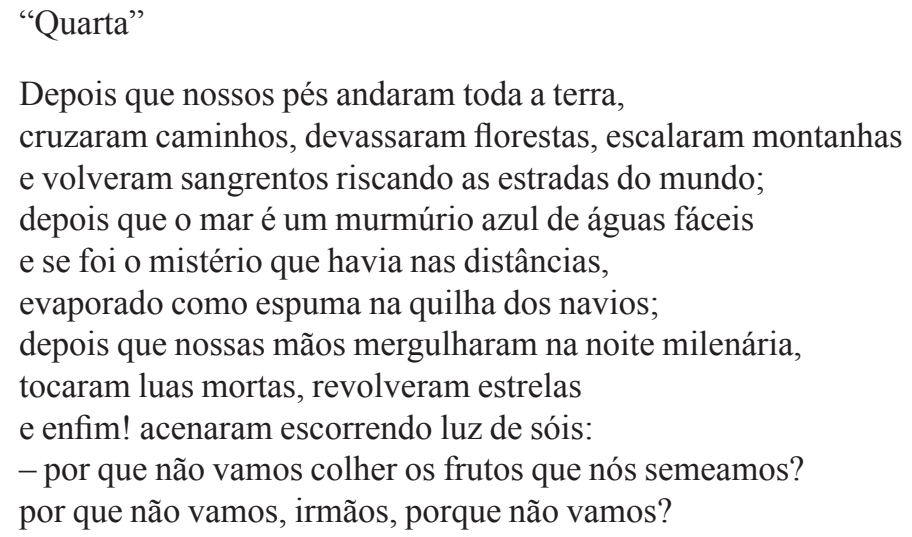

(FONSECA, 1969, p. 13)

Dentre os espaços que se concretizam por meio das "figuras poéticas" de que falou Seixo, o mar parece ocupar uma posição intermédia, posto entre o que há na terra ("caminhos", "florestas" e "montanhas") e o etéreo ("luas", "estrelas" e "sóis"). Das coisas humanas, é, o mar, a mais remota, mas nem por isso oculta à experiência humana, pois "se foi o mistério que havia nas distâncias", uma vez que desvendado pelos portugueses. Aparece, no fim de contas, como uma das escalas - terra, mar e ar - que conduzem aos questionamentos no final do poema.

Uma vez descoberto em sua amplidão, o mar se converte no plano da desmedida, da ânsia de fazer a revolução (no sentido mais amplo que o lexema possa assumir). A base mais à mão, evidentemente, encontra-se na "Ode Marítima", de Allvaro de Campos, referida por mais de um crítico como poema de culto entre os neorrealistas (cf. LOURENÇO, 1983, p. 101; ${ }^{9}$ SEIXO, 2011, p. 62): "Ser o pirata-resumo de toda a pirataria no seu auge, / $\mathrm{E}$ a vítima-síntese, mas de carne e osso, de todos os piratas do mundo!" (PESSOA, 1995, p. 166). É de se notar, entrementes, que a evocação do passado marítimo a partir do que se vê no presente já está em "O Sentimento dum Ocidental”, de Cesário Verde: "E evoco, então, as crónicas navais: / Mouros, baixéis, heróis, tudo ressuscitado!/ Luta Camões no Sul, salvando um livro a nado! / Singram soberbas naus

\footnotetext{
${ }^{9}$ Vale salientar que, tendo em mente "Aviso à navegação", de Joaquim Namorado, o crítico fale numa recuperação tomada à letra, opostas que estão a atmosfera onírica elaborada pelo poeta de Orpheu e a materialista encampada por Namorado (LOURENÇO, 1983, p. 101).
} 
que eu não verei jamais!" (VERDE, 1992, p. 102). Na "Sétima" das "Sete canções da vida", o eu poético se sente "como pirata à hora da abordagem", gritando e estremecendo e ansiando pela "Vida!"; assim mesmo, com inicial maiúscula (FONSECA, 1969, p. 16-17). ${ }^{10} \mathrm{O}$ mar é a via, portanto, para a liberdade.

A nota de rebeldia que se delineia no anseio pela pirataria também se configura noutros tons. $\mathrm{O}$ mar, então, surge como o espaço da natureza que se abre para o mundo; e que abre o próprio mundo, em que o eu poético é convidado pela voz da ave e do vento a participar de uma união, integrando-se e tornando-se livre como aquilo que o envolve. Em "Partir", a segunda das "Canções da beira-mar", lê-se:

Passa a ave no céu bebendo azul e diz: - Vem!

$\mathrm{O}$ vento envolve-me numa carícia, envolve-me e murmura: - Vem!

As ondas estalam nas praias e vão mar fora, as mãos de espuma a prender-me os sentidos chamam no fundos dos meus olhos: - Vem! (FONSECA, 1969, p. 24)

O desejo de partir "para além do Tejo" destoa, p. ex., da resiliência do pastor de D. Francisco Manuel de Melo, que, no soneto "Desgraça, inveja de tudo", diz: "Corre alegre e soberbo, ó doce Tejo, / pois vives sem fortuna, de que esperes / que encaminhe teu passo a teu desejo. // Vás e tornas é irás como vieres. / Ditoso tu, que vês o que eu não vejo; /ditosotu,quevásadondequeres!"' (MELO, 1921, p. 47). Moderno, o eu lírico de Fonseca deseja ir adiante. Nesse sentido, avizinha-se, por vias distintas, de um outro antecedente (este, imediato) no plano da Literatura Portuguesa, o presencista José Régio. Enquanto que, no "Cântico Negro", o poeta vila-condense assim responde ao convite dos integrantes da ordem instituída: "Quando me dizem: 'vem por aqui!' / Eu olho-os com olhos lassos, / (Há, nos olhos meus, ironias

\footnotetext{
${ }^{10}$ Pelo menos em três outros poemas que contemplam o mar o lexema vida é grafado com inicial maiúscula. Em "Partir", que se comenta na sequência: "Grita-me a Vida de longe / e eu vou-me embora para além do Tejo." (FONSECA, 1969, p. 23); em "O vagabundo do mar": É por isso, meus amigos, / que a tempestade da Vida / me apanhou no alto mar."; e em "Canção da beira-mar": "Que ansiedade de mar largo, / ai que desejo de Vida!" (FONSECA, 1969, p. 26. A vida plena só pode ser proporcionada pela liberdade e pela desmesura do mar: "Quando nos levas mar? / Quando começa a Vida?" (FONSECA, 1969, p. 27)
} 
e cansaços) / E cruzo os braços, / E nunca vou por ali..." (RÉGIO, 1994, p. 430); em "Partir", o desejo de se contrapor a regras (por motivações diversas das de Régio, já se vê) materializa-se na aceitação do convite às instâncias naturais, tão caras à produção de Fonseca e marcantes em Rosa dos ventos. Com as voltas que separam os dois projetos literários, não soa a falácia pensar em vieses que se completam e mostram duas faces da mesma moeda (moderna): o homem não deve repisar o já dito e o já feito, bem como deve ser capaz de desbravar o mundo por suas próprias ideias e por sua própria força. Ou, conforme o poeta neorrealista, "- Ai as desgraças humanas destas paisagens iguais!..." (FONSECA, 1969, p. 23).

Outra modalidade de voz que ascende na lírica de Manuel da Fonseca é aquela que acima se comentou - à luz de T. S. Eliot -, na qual se oferece a uma personagem dramática o direito de enunciar; tendência, vale dizer, que se respalda tanto no romance tradicional castelhano, como, em medida mais específica, na lírica de Federico García Lorca. A figura do vagabundo, que se materializa em passagens de verso e de prosa na Literatura do poeta santiaguense, faz-se presente, em sua lírica, em conjunção com o mar no poema "O vagabundo do mar", quarta das "Canções da beira-mar":

Sou barco de vela e remo
sou vagabundo do mar.
Não tenho escala marcada
nem hora para chegar:
é tudo conforme o vento,
tudo conforme a maré... (FONSECA, 1969, p. 28)

Algo daquilo que se poderá ver no "Poema da malta das naus", de António Gedeão, já está aqui, mas não com a mesma ancoragem (GEDEÃO, 1987, p. 82-83). Enquanto que, no poeta-cientista, a vinculação à História (com sua revisão) dá o tom, no poema de Fonseca, é um modo de ser diante da vida que prevalece; do vagabundo que tanto se pode movimentar pelos campos alentejanos, quanto pelo mar, e cujos espaços parecem uma sinédoque da própria existência - sem rumo, sem planos, mas com a "Vida". Em "Noturno", poema da série "O vagabundo e outros motivos ribatejanos", uma ambiência recorrente nos contos de Manuel da Fonseca - o largo - comporta uma outra personagem a quem a voz é concedida e que fala de suas experiências com o mar (aqui, mais concreto que o do "Vagabundo do mar"). 


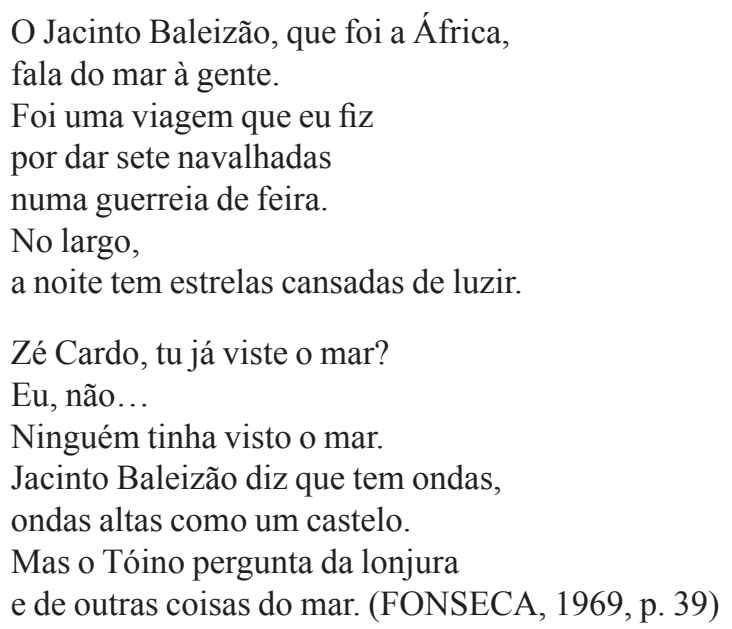

Não nomeado como tal, Jacinto Baleizão é o maltês que, enviado a outras plagas - e pela via marítima - como decorrência de uma refrega em que se envolve, sabe do que os companheiros não sabe. O que, para um, é realidade palpável, conhecida em primeira mão, é, para os outros, mistério e "lonjura", dos que não tiveram a experiência. Contraposta à visão do "moço do interior" de "Saudade", também fruto do contato com a instância retratada, a de Jacinto Baleizão tem maior lastro vivencial. Entrementes - no recurso à metapoesia, não rara no Neorrealismo (cf. REIS, 1983, p. 79) -, conforme dito em "Os olhos do poeta", nestes estão "os tesouros dos oceanos desvendados maravilhando como contos-de-fada à hora da infância", dentre tantas outras experiências humanas. Por isso, seu olhar "é um farol erguido no alto de um promontório" (FONSECA, 1969 , p. 68). Assim, por meio das figuras - o mar, inclusive -, pode-se abarcar todo o mundo e o iluminar. Muito mais que uma série de palavras que rechacem uma conjuntura imediata, a lírica de Manuel da Fonseca reflete sobre a condição humana e sobre a própria poesia. E o mar, não restam dúvidas, é um dos caminhos para tal. 


\section{Referências}

ADORNO, T. W. Palestra sobre lírica e sociedade. In: . Notas de Literatura I. São Paulo: Duas Cidades; 34, 2003. p. 65-89.

BELCHIOR, M. de L. Da poesia de Manuel da Fonseca ou a demanda do paraíso. In: BELCHIOR, M. de L.; ROCHETA, M. I.; SEIXO, M. A. Três ensaios sobre a obra de Manuel da Fonseca. Lisboa: Seara Nova; Comunicação, 1980. p. 9-49.

BERARDINELLI, A. As muitas vozes da poesia moderna. In:

Da poesia à prosa. São Paulo: Cosac Naify, 2007. p. 17-41.

DIÁLOGO com Manuel da Fonseca. Gazeta musical e de todas as artes, Lisboa, s. 2, n. 109-110, p. 54-58, abr.-maio 1960.

DIONÍSIO, M. Prefácio. In: FONSECA, M. da. Obra poética. 7. ed. Lisboa: Caminho, 1984. p. 17-39.

DIONÍSIO, M. Antiprefácio. In: Martins: Europa-América, [19 . Poesia incompleta. 2. ed. Mem

ELIOT, T. S. O uso da poesia e o uso da crítica: estudos sobre a relação da crítica com a poesia na Inglaterra. São Paulo: É Realizações, 2015.

ELIOT, T. S. The three voices of poetry. In: . On poetry and poets. New York: Noonday, 1969. p. 96-112.

FERREIRA, S. Manuel da Fonseca: memória e verdade da sua poesia e ficção. Colóquio/Letras, Lisboa, n. 94, p. 85-89, nov. 1986.

FILIPE, M. Algumas notas para uma nova poética. In: REIS, Carlos (Sel.). Textos teóricos do Neorrealismo português. Lisboa: Seara Nova; Comunicação, 1981. p. 221-222.

FONSECA, M. da. Obra poética. 7. ed. Lisboa: Caminho, 1984.

FONSECA, M. da. Poemas completos. 3. ed. Lisboa: Portugália, 1969.

FRYE, N. O caminho crítico. São Paulo: Perspectiva, 1973.

GEDEÃO, A. Poesias completas: 1956-1967. 10. ed. Lisboa: Sá da Costa, 1987.

GUIMARÃES, F. Leituras do Neorrealismo: Planície e Aldeia Nova. Nova síntese, Vila Franca de Xira, n. 6, p. 67-71, 2011. 
GUSMÃO, M. A poesia de Manuel da Fonseca e o Alentejo. Nova síntese, Vila Franca de Xira, n. 6, p. 55-66, 2011.

HAMBURGER, M. A verdade da poesia. São Paulo: Cosac Naify, 2007.

LOURENÇO, E. Sentido e forma da poesia neorrealista. 2. ed. Lisboa: Dom Quixote, 1983.

MELO, F. M. de. O poeta melodino. Porto: Companhia Portuguesa, 1921.

PESSOA, F. Antologia poética: seguida do "Livro do desassossego". 2. ed. Lisboa: Ulisséia, 1995.

RÉGIO, J. Cântico negro. In: MOISÉS, M. A Literatura Portuguesa através dos textos. 23. ed. São Paulo: Cultrix, 1994. p. 430-432.

REIS, C. O conhecimento da Literatura: introdução aos estudos literários. 2. ed. Coimbra: Almedina, 2001.

REIS, C. O discurso ideológico do Neorrealismo português. Coimbra: Almedina, 1983.

SEIXO, M. A. Manuel da Fonseca, o olhar do poeta. In: SANTOS; D.; SANTOS, L. D. (Org.). Manuel da Fonseca: por todas as estradas do mundo. Lisboa: Assírio \& Alvim, 2011. p. 55-77.

SIMÕES, J. G. Itinerário histórico da poesia portuguesa: de 1189 a 1964. Lisboa: Arcádia, 1964.

SOUSA, E. de. História e mito. Brasília: Ed. Universidade de Brasília, 1981.

VERDE, C. O sentimento dum ocidental. In: . O livro de Cesário Verde. Lisboa: Ática, 1992. p. 101-111. 